\title{
Department of Energy Treatment Capabilities for Greater-Than-Class C Low-Level Radioactive Waste
}

D. K. Morrell

D. K. Fischer

Published January 1995

Idaho National Engineering Laboratory

Lockheed Idaho Technologies Company National Low-Level Waste Management Program

Idaho Falls, Idaho 83415

Prepared for the

U.S. Department of Energy

Assistant Secretary for Environmental Management

Under DOE Idaho Operations Office

Contract DE-AC07-94ID13223 


\section{DISCLAIMER}

This report was prepared as an account of work sponsored by an agency of the United States Government. Neither the United States Government nor any agency thereof, nor any of their employees, makes any warranty, express or implied, or assumes any legal liability or responsibility for the accuracy, completeness, or usefulness of any information, apparatus, product, or process disclosed, or represents that its use would not infringe privately owned rights. Reference herein to any specific commercial product, process, or service by trade name, trademark, manufacturer, or otherwise does not necessarily constitute or imply its endorsement, recommendation, or favoring by the United States Government or any agency thereof. The views and opinions of authors expressed herein do not necessarily state or reflect those of the United States Government or any agency thereof. 


\section{DISCLAIMER}

Portions of this document may be illegible in electronic image products. Images are produced from the best available original document. 


\begin{abstract}
This report provides brief profiles for 26 low-level and high-level waste treatment capabilities available at the Idaho National Engineering Laboratory (INEL), Lawrence Livermore National Laboratory (LLNL), Los Alamos National Laboratory (LANL), Oak Ridge National Laboratory (ORNL), Pacific Northwest Laboratory (PNL), Rocky Flats Plant (RFP), Savannah River Site (SRS), and West Valley Demonstration Plant (WVDP). Six of the treatments have potential use for greater-than-Class C low-level waste (GTCC LLW). They include: (a) the glass ceramic process and (b) the Waste Experimental Reduction Facility incinerator at INEL; (c) the Super Compaction and Repackaging Facility and (d) microwave melting solidification at RFP; (e) the vitrification plant at SRS; and (f) the vitrification plant at WVDP. No individual treatment has the capability to treat all GTCC LLW streams. It is recommended that complete physical and chemical characterizations be performed for each GTCC waste stream, to permit using multiple treatments for GTCC LLW.
\end{abstract}




\section{SUMMARY}

The U.S. Congress, through Public Law 99-240 (National Low-Level Waste Policy Amendments Act of 1985), assigned responsibility for ensuring the safe disposal of greater-than-Class C low-level radioactive waste (GTCC LLW) to the Department of Energy (DOE). Treatment of GTCC LLW may be necessary to ensure safe disposal.

This report provides information on 26 low-level waste (LLW) and high-level waste (HLW) treatment capabilities located at the Idaho National Engineering Laboratory (INEL), Lawrence Livermore National Laboratory (LLNL), Los Alamos National Laboratory (LANL), Oak Ridge National Laboratory (ORNL), Pacific Northwest Laboratory (PNL), Rocky Flats Plant (RFP), Savannah River Site (SRS), and West Valley Demonstration Plant (WVDP). GTCC LLW is not currently being treated; however, six of the treatment facilities could potentially be used for GTCC LLW. These include: (a) the glass ceramic process and (b) the Waste Experimental Reduction Facility (WERF) incinerator at the INEL; (c) the Super Compaction and Repackaging Facility and (d) Microwave Melting Solidification Facility at the RFP; (e) the Vitrification Plant at the SRS; and (f) the Vitrification Facility at the WVDP. Specific information for these is given. The information includes: (a) feed stock requirements, (b) process functions, (c) throughput rates, (d) limitations, and (e) posttreatment waste forms.

GTCC LLW is commercially generated waste defined in 10 CFR Part 61 as waste with concentrations above Class $\mathrm{C}$ limits for certain short- and long-lived radionuclides. DOE has classified GTCC LLW into four general categories:

\section{Nuclear Utilities}

\section{Sealed Sources}

\section{DOE-Held Potential}

\section{Other Generators.}

Nuclear utility GTCC LLW includes activated metals from standard operations, process wastes (e.g., decontamination resins and cartridge filters), and decommissioning waste. Sealed sources have common uses in medicine, construction, manufacturing, research, and various other fields. Sealed sources become waste when they are no longer needed, or their activity has decayed to an unusable level. DOE-Held waste is GTCC LLW generated by commercial facilities that through contractual arrangements with DOE and/or for health and safety reasons, is being stored by DOE. Other Generator waste is waste from a wide variety of sources [e.g., Carbon-14 users, industrial research and development firms, fuel fabricators and irradiation research (burnup) labs, academic nuclear research reactors, sealed source manufacturers, and nonmedical academic institutions].

Although GTCC LLW is not being treated, the DOE equivalent to Nuclear Regulatory Commission (NRC) Class A, B, and C LLW plus HLW are being treated using various processes and technologies. Of these, the following four are potentially feasible for treating GTCC LLW:

1. Vitrification

2. Cement Matrix Solidification 


\section{Incineration}

\section{Compaction.}

The first, vitrification, is the process of converting materials into a glass or glass-like substance. Vitrification is performed by adding glass-forming chemicals known as frit to the waste stream to be treated. The waste mixture is then heated to approximately $1150^{\circ} \mathrm{C}$, causing the glass and waste to melt forming a homogeneous substance.

Vitrification has three major advantages. The primary advantage is the durable waste glass that it produces. This waste glass performs exceptionally well in leach tests. The second major advantage is the flexibility it affords by accepting a wide variety of contaminants and accompanying feed material in its structure without a significant decrease in quality. Lastly, the vitrification process can accommodate both organic and inorganic contaminants. There is some concern however, with the treatment of organic contaminants. Organic contaminants have the potential of volatizing, thereby releasing gases. An offgas cleaning system must be operable for the treatment of these contaminants. Pretreatment of waste materials containing organic contaminants is preferred. Incineration is a good example of a preferred pretreatment.

Cement matrix solidification will immobilize chemical or radioactive hazards by providing a solid waste form, limiting surface area available for leaching, and limiting the solubility of the waste.

Incineration yields high volume reduction and converts the organic bulk material into stable ashes and residues. Net volume and weight reduction factors of up to 100 and 20 , respectively, are achieved.

Compaction is a mechanical volume reduction process in which waste material is compressed in disposal containers. Super compaction can achieve a 2-4 volume reduction factor for hard-to-compact waste (e.g., metal components, piping, filters, wood, and cinderblock), and a 6-7 volume reduction factor for compactible waste (e.g., paper, plastic, cloth, rubber, and cardboard).

This study determined that facilities do exist within the DOE complex to treat GTCC LLW on a waste-stream-specific basis. However, none are currently treating GTCC LLW or its governmentgenerated equivalent known as Special Case Waste. Introducing GTCC LLW as an added waste stream to operational or near-operational facilities would seriously impede their activities. The most viable options are DOE capabilities that are in the early phase of development (i.e., PNL Low-Level Waste Vitrification Facility at Hanford, experimental microwave melter process at RFP). 


\section{CONTENTS}

ABSTRACT $\ldots \ldots \ldots \ldots \ldots \ldots \ldots \ldots \ldots \ldots \ldots \ldots \ldots \ldots \ldots \ldots \ldots \ldots$

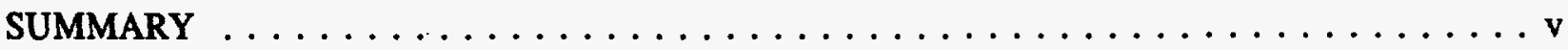

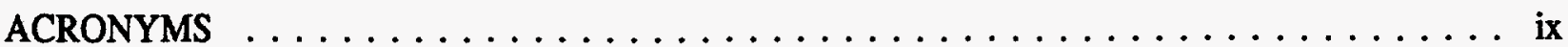

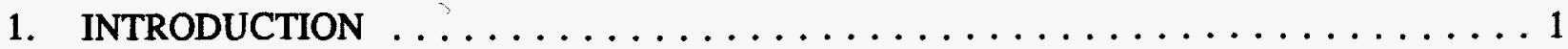

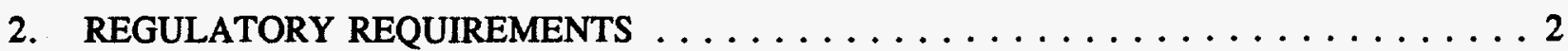

2.1 Low-Level Radioactive Waste Policy Amendments Act of $1985 \ldots \ldots \ldots$. . . . . . 2

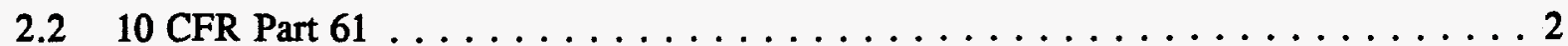

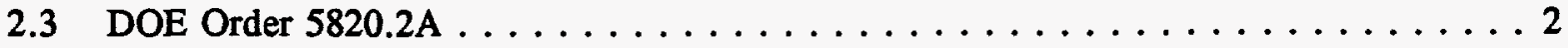

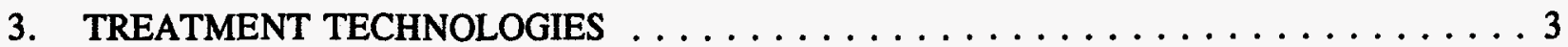

3.1 GTCC LLW Treatment Technology Evaluation $\ldots \ldots \ldots \ldots \ldots \ldots \ldots$

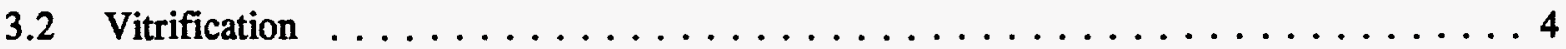

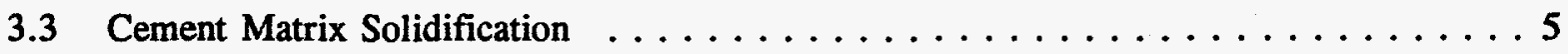

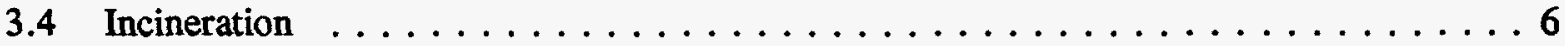

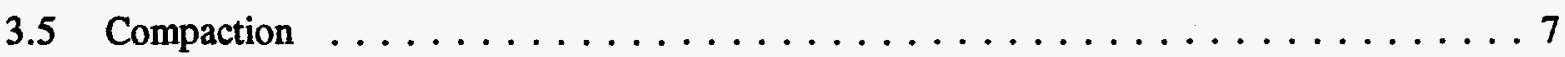

4. DEPARTMENT OF ENERGY TREATMENT CAPABILITIES $\ldots \ldots \ldots \ldots$

4.1 Idaho National Engineering Laboratory $\ldots \ldots \ldots \ldots \ldots \ldots \ldots \ldots$

$4.1 .1 \quad$ Glass Ceramic Process . . . . . . . . . . . . . . . . . 14

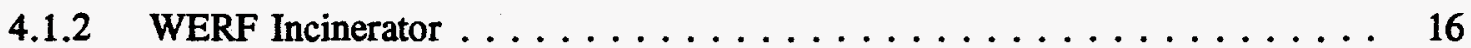

4.2 Rocky Flats Plant $\ldots \ldots \ldots \ldots \ldots \ldots \ldots \ldots \ldots$

4.2.1 Super Compaction and Repackaging Facility $\ldots \ldots \ldots \ldots \ldots \ldots$

4.2 .2 Microwave Melting Solidification . . . . . . . . . . . . 18

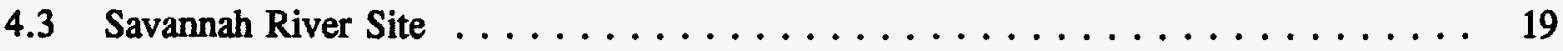

4.3.1 DWPF Vitrification Plant $\ldots \ldots \ldots \ldots \ldots \ldots \ldots \ldots \ldots \ldots \ldots \ldots \ldots$ 


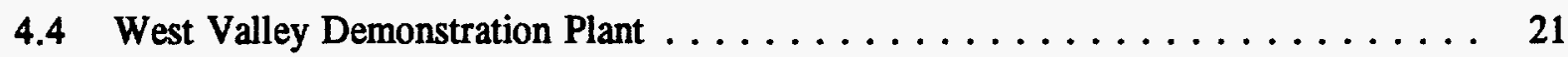

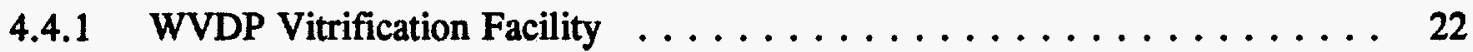

5. CONCLUSIONS AND RECOMMENDATIONS $\ldots \ldots \ldots \ldots \ldots \ldots \ldots$

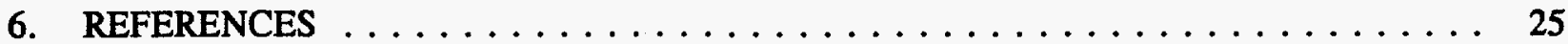

Appendix A-Greater-Than-Class C Low-Level Waste Characterization . . . . . . . . . . A-1

\section{TABLES}

1. Treatment technology evaluation results $\ldots \ldots \ldots \ldots \ldots \ldots \ldots \ldots$

A-1. GTCC activated metal reactor components $\ldots \ldots \ldots \ldots \ldots \ldots \ldots$

A-2. $\quad$ GTCC reactor process wastes $\ldots \ldots \ldots \ldots \ldots \ldots \ldots \ldots \ldots \ldots$

A-3. Summary of applications using radioactive sealed sources that are GTCC LLW. . . . . A-7

A-4. DOE-held potential GTCC LLW $\ldots \ldots \ldots \ldots \ldots \ldots \ldots \ldots \ldots$

A-5. Other generators $\ldots \ldots \ldots \ldots \ldots \ldots \ldots \ldots \ldots \ldots \ldots \ldots \ldots \ldots \ldots \ldots$ 


\section{ACRONYMS}

DOE Department of Energy

DWPF Defense Waste Processing Facility

GTCC greater-than-Class C

HLW high-level waste

ICPP Idaho Chemical Processing Plant

INEL Idaho National Engineering Laboratory

LANL Los Alamos National Laboratory

LLNL Lawrence Livermore National Laboratory

LLW low-level waste

MFT Melter Feed Tank

NRC Nuclear Regulatory Commission

ORNL Oak Ridge National Laboratory

PHA precipitated hydrolysis aqueous

PNL Pacific Northwest Laboratory

RFP Rocky Flats Plant

RWMC Radioactive Waste Management Complex

SCW Special Case Waste

SME Slurry Mix Evaporator

SRS Savannah River Site

WERF Waste Experimental Reduction Facility

WVDP West Valley Demonstration Plant 


\section{Department of Energy Treatment Capabilities for Greater-Than-Class C Low-Level Radioactive Waste}

\section{INTRODUCTION}

This report identifies potential Department of Energy (DOE) treatment capabilities for greater-thanClass C low-level radioactive waste (GTCC LLW). The information contained in this report was gathered via telephone contacts and site visits. The DOE facilities performing low-level waste (LLW) treatment include the following: Idaho National Engineering Laboratory (INEL), Lawrence Livermore National Laboratory (LLNL), Los Alamos National Laboratory (LANL), Oak Ridge National Laboratory (ORNL), Pacific Northwest Laboratory (PNL), Rocky Flats Plant (RFP), Savannah River Site (SRS), and West Valley Demonstration Plant (WVDP). None of the facilities listed are currently treating GTCC LLW.

The report is organized as follows: Section 1 provides the introduction. Section 2 discusses the regulatory requirements that govern the management of GTCC LLW. These requirements are the LowLevel Radioactive Waste Policy Amendments Act of 1985, 10 Code of Federal Regulations (CFR) Part 61, and DOE Order 5820.2A, "Radioactive Waste Management." Section 3 summarizes treatment technologies currently being studied for the treatment of GTCC LLW. Four specific technologies discussed are (a) vitrification, (b) cement matrix solidification, (c) incineration, and (d) compaction. General operating processes and advantages and disadvantages of each are identified. Section 4 identifies the 26 DOE LLW treatment capabilities located at the National Laboratories listed above. It also contains specific information on the six treatment capabilities that are considered feasible for the treatment of GTCC LLW. The information given includes feed stock requirements, process functions, throughput rates, limitations, and post-treatment waste forms. Rough order-of-magnitude cost estimates were not available. Section 5 contains conclusions and recommendations. Section 6 lists the references cited. Appendix A identifies commercial facilities that generate potential GTCC LLW. Also, GTCC LLW volume and waste form information gathered to date is given. The four general categories of waste generators are identified and discussed. 


\section{REGULATORY REQUIREMENTS}

The management and treatment of GTCC LLW is governed by the Low-Level Radioactive Waste Policy Amendments Act of 1985, NRC regulations, and DOE orders. Each is discussed below.

\subsection{Low-Level Radioactive Waste Policy Amendments Act of 1985}

The Low-Level Radioactive Waste Policy Amendments Act of 1985 (herein referred to as the Act) assigned DOE the responsibility of ensuring the safe disposal of GTCC LLW. It further requires that GTCC LLW generated by licensees of the NRC and Agreement States be disposed of in a facility licensed by the NRC. The GTCC LLW Program was initiated in response to the Act.

\subsection{CFR Part 61}

In 1983, 10 CFR Part 61 codified disposal requirements for three classes of LLW considered generally suitable for near-surface disposal: Class $\mathrm{A}, \mathrm{B}$, and $\mathrm{C}$, with Class $\mathrm{C}$ waste requiring the most rigorous disposal criteria. Waste with concentrations above Class $\mathrm{C}$ limits for certain short- and longlived radionuclides, but not defined as HLW or spent nuclear fuel, is known as GTCC LLW. GTCC LLW is not suitable for near-surface disposal, except on a case-by-case basis.

\subsection{DOE Order 5820.2A}

DOE Order 5820.2A, "Radioactive Waste Management," ${ }^{1}$ does not outline policies specifically for GTCC LLW generated by NRC licensees. It does, however, establish policies, guidelines, and minimum requirements by which DOE manages radioactive and mixed waste. The order could serve as guidance for GTCC LLW Program treatment development. Chapter III, Paragraph 3 (f-2) states

Waste treatment techniques such as incineration, shredding, and compaction to reduce volume and provide more stable waste forms shall be implemented as necessary to meet performance requirements. Use of waste treatment techniques to increase the life of the disposal facility and improve long-term facility performance, by improving site stability and reduction of infiltrating water, is required to the extent it is cost effective.

The Order also directs DOE to comply with all regulations promulgated by the NRC and the U.S. Environmental Protection Agency, including all technical requirements.

The expected GTCC LLW streams are identified in Appendix A. The waste must be treated to provide a stable waste form for disposal or long-term storage. Treatment technologies capable of treating GTCC LLW are described in the following section. 


\section{TREATMENT TECHNOLOGIES}

Currently, various processes and technologies are used to treat DOE equivalent Class A, B, and C LLW, and HLW. However, no treatment of GTCC LLW or DOE equivalent Special Case Waste (SCW) is currently being performed. Several of the technologies used for the other waste classes are potentially feasible for the treatment of GTCC LLW and SCW.

\subsection{GTCC LLW Treatment Technology Evaluation}

A thorough review sought to identify technology types that could treat GTCC LLW and produce a waste form that would satisfy DOE Order 5820.2A. This review is documented in the Greater-ThanClass C Low-Level Radioactive Waste Treatment Technology Evaluation report. ${ }^{2}$ To best evaluate the treatment alternatives, four waste processing groups were developed: (a) all waste streams combined, (b) sealed sources only, (c) activated metals only, and (d) combustibles only. Table 1 contains the results of the evaluation and identifies treatment technology types and their associated processing options.

Four of the technology types identified are addressed in this section. These include vitrification, cement matrix solidification, incineration, and compaction.

Table 1. Treatment technology evaluation results. ${ }^{2}$

\begin{tabular}{ll}
\hline \multicolumn{1}{c}{ Technology type } & \multicolumn{1}{c}{ Waste processing groups } \\
\hline $\begin{array}{c}\text { Solidification/stabilization } \\
\text { Vitrification } \\
\text { Cement Matrices } \\
\text { Epoxy Matrices }\end{array}$ & All waste streams combined \\
Thermal oxidation/incineration & \\
Oil incineration & All waste streams combined \\
Volume Reduction & \\
Super compaction & All waste streams combined \\
Shredding of waste & \\
Decontamination & \\
Recycling & \\
No Action & \\
Macro-encapsulation & Sealed sources \\
Technology Evaluation, DoE/LLW-159, EG\&G Idaho, Inc., January 1993, Table 4.
\end{tabular}




\subsection{Vitrification}

Vitrification is the process of converting materials into a glass or glass-like substance through heat fusion. ${ }^{3,4}$ Vitrification is conceptually attractive because of the potential durability of the product and the flexibility of the process in treating a wide variety of waste streams and contaminants. These characteristics make vitrification the focal point for treating HLW and a viable treatment for GTCC LLW.

Vitrification has three major advantages. The primary advantage is the durable waste glass that it produces. This waste glass performs exceptionally well in leach tests. The second major advantage is the flexibility of the waste glass in incorporating a wide variety of contaminants, and accompanying feed material in its structure without a significant decrease in quality. Lastly, vitrification can accommodate both organic and inorganic contaminants.

The major limitation of vitrification is that it is energy intensive, and thus may be more expensive compared with other treatment technologies. As stated previously, vitrification can accommodate organic contaminants. However, a second major limitation is the potential for these contaminants to volatilize. An offgas cleaning system must be operable if organic contaminants are subjected to vitrification. Pretreatment of waste materials containing organic contaminants is preferred. An example of pretreatment includes incineration. Incineration volatizes the organic constituents leaving an ash that is then vitrified for disposal. The following may also limit the effectiveness of vitrification:

- $\quad$ Feed moisture content

- Feed material composition

- $\quad$ Feed compatibility

- Presence of combustible material

- Potential electrical shorting caused by metals.

Waste materials can be immobilized in a glass matrix by two main interactions:

- Chemical bonding

- Encapsulation.

Certain inorganic materials can be immobilized by chemical bonding with glass-forming materials called frit. Frit comprises the chemical constituents necessary to provide a durable borosilicate waste glass product. Actual frit composition varies as needed to ensure the production of waste glass that meets disposal requirements. However, the constituents that make up an example batch of frit (Frit 202) includes major oxide components (e.g., $\mathrm{SiO}_{2}, \mathrm{Na}_{2} \mathrm{O}, \mathrm{B}_{2} \mathrm{O}_{3}, \mathrm{Li}_{2} \mathrm{O}$, and $\mathrm{MgO}$ ). Minor frit components include $\mathrm{Al}, \mathrm{Fe}, \mathrm{Mn}, \mathrm{Ni}, \mathrm{Cr}, \mathrm{Pb}, \mathrm{Ti}, \mathrm{F}$, and $\mathrm{Cl}$.

Waste may also be immobilized without direct chemical interaction with the frit. Since vitrification constitutes a molten phase during some portion of the process, materials that do not interact chemically 
or have not completely entered solution can be surrounded by vitrified material and encapsulated as the melt cools. As the glass cools, process cracks propagate, thereby providing the potential for leaching.

The following are various forms of waste to which vitrification potentially applies:

- Radioactive wastes and sludges (e.g., decontamination sludges and liquids, mixed oxide fuel pellets, hot cell waste fuel grinds, glass, filters)

- Contaminated soils

- Incinerator ashes

- Medical wastes (e.g., tracer isotopes used for medical therapy research).

Two material classifications that are marginal for vitrification are metallic wastes and combustible materials. Waste glass will retain metals with varying efficiency depending on the type of vitrification process used, its operating parameters, and the chemical composition of the glass. The presence of metals in the feed may present another problem: shorting of the electrodes used in joule heating. The metals may sink to the bottom of the melt, concentrate there, and possibly create a conduction path that may lead to electrical shorting between the electrodes. An additional concern is the buildup of metal slag in the bottom of the vessel thereby shortening the working life of the vitrification unit.

Combustible materials, including combustible solids, liquids, organics, etc., are also of concern. The main concern with combustible materials is that the gases they generate will carry contaminants to the glass surface and away from the melt to the offgas system.

Although vitrification is not considered the best technology available for treatment of all GTCC $\mathrm{LLW}$, it is potentially valuable for several waste streams. These streams include: (a) salts, (b) silica gels, (c) mixed oxide fuel pellets/rods, (d) fuel grinds, (e) glass materials, (f) metal oxides, (g) incinerator ashes, and (h) decontamination wastes: sludges, filters, and grits. Other GTCC LLW streams are compatible with other available treatment technologies.

\subsection{Cement Matrix Solidification}

Cement matrix solidification is designed to immobilize chemical or radioactive hazards by providing a solid waste form, limiting surface area available for leaching, and limiting the solubility of the waste. ${ }^{3}$ Cement solidification is performed by mixing cement and aqueous waste, or cement, water, and solid waste (e.g., ion-exchange resins, filter sludges, or mechanical assemblies).

Two types of systems have been used in the past for solidification of wastes. The first type uses "in-drum" mixing. The cement and solid wastes are mixed and placed into a disposal container. Liquid is added, and either the container is rotated, or a mixer is placed into the container to mix the constituents. The second type mixes wastes, cement, and finely sized solids in an external mixer. This mixture is placed into containers through hoses or chutes. With external mixing, coarse (larger-sized) solid waste is placed into the container prior to adding the cement mixture.

Advantages of cement matrix solidification include: 
- Material and technology are well known and available

- LLW has been successfully treated in the nuclear power industry

- Treatment cost is relatively low

- Waste form provides good self-shielding

- Waste form has good impact and compressive strength, low leachability, and does not leave water if properly formulated.

Disadvantages of cement matrix solidification include:

- Systems with external mixers require cleanup immediately following completion of solidification

- Cement-based systems add significantly to the total waste volume.

Solidification technology is potentially valuable for some GTCC LLW waste streams. These streams include: (a) liquid wastes, (b) small metal scrap, (c) small mechanical components, (d) ion exchange resins, (e) filter sludge, and (f) filter media. However, it must be recognized that solidification increases the total volume of waste product.

\subsection{Incineration}

At the present time, the most efficient way to treat combustible wastes is incineration. ${ }^{3}$ Incineration leads to the highest volume reduction possible, and converts organic bulk material into stable ashes and residues suitable for further treatment into waste forms that qualify for safe storage and disposal. Vitrification of incinerator ash is a good example of further treatments available.

Incineration has the highest overall volume reduction factor when compared with other known treatment and conditioning procedures for combustible wastes. Net volume and weight reduction factors of up to 100 and 20 , respectively, are achieved.

Due to the high volume reduction achieved during incineration, a reciprocal increase in the specific activity takes place in the ashes. Care has to be taken of this phenomenon, especially as far as the radiation exposure to operational personnel is concerned.

Several process steps are involved in the safe combustion of radioactive wastes:

- Waste should be sorted before incineration. Sorting assures more homogenous feed, resulting in smooth and complete incineration, control of combustion and reduced risk of accumulating unburnt material in the ashes and the offgas system.

- The temperature of the furnace is maintained between 700 and $1,100^{\circ} \mathrm{C}$ to ensure complete combustion of the waste material. 
- The combustion gas must be cooled and cleaned to protect the environment from the release of noxious gases.

- Sufficient ash collection points must be provided to permit cleaning of the entire furnace system. The ash must be treated further to prepare it for storage and disposal.

Offgases from incineration can be highly corrosive, requiring precautions and construction materials that can withstand corrosion. The combustion gases leaving the furnace generally are at temperatures near $1,100^{\circ} \mathrm{C}$. Cleaning of the offgases normally starts with a cooling step, followed by a wet or dry or a combined cleaning procedure. The final purification is normally carried out by high-efficiency gas filters. The offgas cleaning process is also used to separate entrained radioactive particulates from the offgas.

Advantages of incineration processes include:

- Destruction of combustible hazardous materials

- $\quad$ Size and volume reduction of waste

- Production of more easily-handled waste forms

- Ability to process various waste forms and flow rates.

Disadvantages of incineration processes include:

- $\quad$ Required preparation of the waste before incineration

- Occasional-to-frequent maintenance

- $\quad$ Required further treatment of output ash materials

- Lag time between incinerator shutdown and final burnout of the waste is a critical factor in an emergency situation

- Buildup of residual slag, dust, and other materials that require manual cleanout

- Dependence on the offgas system to control gaseous and particulate emissions, even in the event of catastrophic failure of system components (backup systems required).

Currently, incineration must be considered as one of the best available technologies for the treatment of specific GTCC LLW streams (organic liquids, absorbed liquids, alcohols, sludges, filters, rags, plastics, cloth, etc.).

\subsection{Compaction}

Compaction is a mechanical volume reduction process by which waste material is compressed in disposal containers. ${ }^{3}$ Volume reduction achieved during compaction is a function of void space in the 
waste package, the force applied by the press, the bulk density of the material, and its springback characteristics. Super compactors with ram pressures ranging from 5,200 to 11,400 psig are capable of compacting traditionally noncompactible waste. Such super compactors can achieve a 2-4 volume reduction factor for noncompactible waste, and a 6-7 volume reduction factor for compactible waste.

Advantages of compaction processes include:

- Compaction is a proven process used throughout the world in the nuclear industry

- Compaction systems are simple, and tend to be reliable and trouble-free

- Waste compaction is relatively inexpensive

- The process is simple to operate

- The contaminated surface area is reduced and the compacted form makes the constituent waste items more stable than they would be if just freely residing in a container.

Disadvantages of compaction processes are that

- Compaction is not recommended for wastes containing free liquids

- Compaction should not be used on very dense or bulky items where minimum volume reduction would be achieved.

Compaction is a viable treatment technology for various GTCC LLW streams. These include: activated metals, glasses, contaminated solids, plastics, small equipment and tools, filters, compactible trash, wood, pipes, etc.

Vitrification, solidification, incineration, and compaction facilities exist at the DOE operated National Laboratories. In Section 4 , these capabilities will be identified. 


\section{DEPARTMENT OF ENERGY TREATMENT CAPABILITIES}

A total of 26 DOE treatment capabilities were identified. The treatment capabilities exist at eight DOE-operated facilities, which comprise the INEL, LLNL, LANL, ORNL, PNL, RFP, SRS, and WVDP. All DOE treatment capabilities identified for LLW are summarized below. Each is identified by the laboratory location; process or facility available or planned; and status of process or facility. These status indicators are "operational," "nonoperational," "planned," or "under-construction." Of the 26 DOE treatment capabilities identified, six are considered of potential interest to the GTCC LLW Program. Each of these is discussed in-depth later in this section.

- Idaho National Engineering Laboratory (INEL)

Glass Ceramic Process

(Planned)

The Glass Ceramic Process (currently being tested) is of interest to the GTCC LLW Program. The process is discussed in Section 4.1.1.

- INEL

Mixed and Low-Level Waste Treatment Facility

(Planned)

The first Mixed and Low-Level Waste Treatment Facility is in the planning stages. However, current funding has been shifted to higher priority projects. Treatment at the new facility would include:

- Coarse sizing and incineration of combustible LLW

- $\quad$ Portland cement stabilization of ash, sludges, slurries, and secondary waste streams

- Compaction of compactible LLW

- Liquid treatment consistent with the characteristics of the liquid

- Organics thermally treated and aqueous waste stabilized or thermally treated

- Noncompactible LLW sized and repackaged

No specific information is currently available on facility design or individual treatment processes. The estimated startup date for this facility is January 2007.

- INEL

Idaho Waste Processing Facility

(Planned)

The Idaho Waste Processing Facility will become the cornerstone for transuranic (TRU) waste management at the INEL. The facility will be constructed in phases, with each phase resulting in a fully operational facility. Phase I includes the basic facility to handle segregated alpha- 
LLW. Included in this phase will be processes and equipment for recycling and preprocessing, thermal treatment, and immobilization. Phase II will provide the capability to process TRU and mixed TRU waste. It includes processes for metal decontamination and or casting, soil processing, remote-handled waste, and plutonium recovery. No specific information is currently available on facility design or individual treatment processes. The estimated startup date for this facility is January 2005.

- INEL

Waste Experimental Reduction Facility (WERF) Compactor

(Nonoperational)

The facility was shutdown for safety concerns and is currently nonoperational. The compactor, a 200-ton in-box compactor, was used for compaction of light gauge metals, plastics, wood, filters, etc. The average output was 65 to 70 tons per year. The majority of GTCC LLW is in the form of activated heavy gauge metals which are incompatible with this facility.

- INEL

WERF Incinerator

(Nonoperational)

The controlled air incineration facility is discussed in Section 4.1.2.

- INEL

WERF Grout Facility

(Nonoperational)

The grout facility stabilizes the resultant WERF incinerator ash. Section 4.1 .2 discusses the facility in conjunction with WERF incineration.

- INEL

WERF Sizing Facility

(Nonoperational)

Size reduction of large metal components and other oversized structures was performed using plasma torch technology. The sized pieces were then repackaged and disposed of at the Radioactive Waste Management Complex (RWMC). The facility was shutdown based on safety concerns, and is not planned for restart.

- Lawrence Livermore National Laboratory (LLNL)

Decontamination and Waste Treatment Facility

(Planned)

The Decontamination and Waste Treatment Facility is currently in the design phase. Incineration is the proposed waste treatment process. No additional information is available at this time. 
- LLNL

Shredding Unit

(Operational)

The shredding unit consists of a shredder and a drum dumping assembly. A 55-gal drum of waste is loaded into the assembly, locked into place, raised up, and the contents dumped into the shredder. The contents are shredded and exit below the unit into another 55-gal drum.

- LLNL

Solidification Unit

(Nonoperational)

Aqueous waste stored in 30-gal drums is solidified by the addition of Envirostone, a cementing agent. The waste and cement are mixed thoroughly and allowed to harden. When in operation, 500 drums per month were processed. There are no plans to operate this facility in the future.

- Los Alamos National Laboratory (LANL)

Compactor

(Nonoperational)

The nonoperational baling compactor was used for the baling of soft waste (paper, plastic, clothing, rubber, etc.). The soft waste was loaded into the baler, compacted, banded, sealed in plastic and shipped to disposal. LANL is in the process of upgrading to a larger compactor, but no additional information is available.

- LANL

Controlled Air Incinerator

(Nonoperational)

The controlled air incinerator at LANL is currently nonoperational. The incinerator design is similar to the facility located at INEL. For a description of similar facility operations refer to Section 4.1.2.

- $\quad$ Oak Ridge National Laboratory (ORNL)

Compactor

(Operational)

The 75-ton in-drum compactor processes soft waste (paper, plastic, clothing, rubber, etc.) This is not compatible with the expected GTCC LLW streams. 
- ORNL

K-1421 Waste Incinerator

(Nonoperational)

The Incinerator Facility at ORNL is currently nonoperational and there are no plans to restart in the future. When operational, the incinerator treated general combustible trash (clothing, gloves, paper, etc.).

- ORNL

Waste Feed Preparation Facility

(Operational)

The Waste Feed Preparation Facility baling compactor is used for the baling of soft waste (paper, plastic, clothing, rubber, etc.). The soft waste is loaded into the 200-ton baler, compacted, banded, sealed in plastic, loaded into a B-25 overpack box and shipped to disposal. This is not compatible with the expected GTCC LLW streams.

- Pacific Northwest Laboratory (PNL)

Grout Treatment Facility

(Nonoperational)

In the Grout Treatment Facility, dry cementitious material is mixed with sampled aqueous waste to form a grout slurry. The slurry is pumped into subsurface vaults where it solidifies. The formula for the cementitious material is based on results of the sample analysis. There are no plans to restart this facility.

- PNL

Hanford Waste Vitrification Plant

(Under Construction)

PNL is in the process of designing and constructing a High-Level Waste Vitrification Facility. Support structures have been fabricated and the site excavation is complete. The project is in Phase 2 Design, but was recently put on hold. At the earliest, construction of the HighLevel Waste Vitrification Facility will continue in FY 1997.

- $\quad$ PNL

\section{LLW Vitrification Plant \\ (Planned)}

Personnel at PNL are in the process of designing a Low-Level Waste Vitrification Facility. The project is currently in the early stages of preconceptual design. No additional information is available at this time, but additional investigation for GTCC LLW compatibility should be performed in the future. 
- $\quad$ PNL

Waste Receiving and Processing Facility-IIA

(Planned)

The Waste Receiving and Processing Facility at PNL is currently in the design phase. Proposed treatments include compaction, solidification, shredding, and size reduction. No additional information is available at this time, but additional investigation for GTCC LLW compatibility should be performed in the future.

- Rocky Flats Plant (RFP)

Microwave Melting Solidification

(Planned)

The microwave melting solidification process, currently being tested, is potentially useful for treatment of GTCC LLW. This process is discussed in Section 4.2.2.

- RFP

Fluidized Bed Units: Building 776

(Nonoperational)

This facility ceased operation in December 1983. No future use of this facility is planned.

- $\quad$ RFP

Super Compaction and Repackaging Facility

(Operational)

The RFP super compaction facility is discussed in Section 4.2.1.

- Savannah River Site (SRS)

Defense Waste Processing Facility Vitrification Plant

(Under Construction)

The vitrification facility, scheduled for cold waste processing startup in June 1994, is discussed in Section 4.3.1.

- $\quad$ SRS

H-Area Compactor

(Operational)

The in-drum compactor located at the H-Area processes soft waste (paper, plastic, clothing, rubber, etc.). This is not compatible with the expected GTCC LLW streams. 
- $\quad$ SRS

M-Area Compactor

(Operational)

The in-drum compactor located at the M-Area processes soft waste (paper, plastic, clothing, rubber, etc.). This is not compatible with the expected GTCC LLW streams.

- West Valley Demonstration Plant (WVDP)

Vitrification Facility

(Under-Construction)

The vitrification facility located at the WVDP is discussed in Section 4.4.1.

Six of the treatment processes identified above is discussed further in Sections 4.1 through 4.4. These are: (a) the glass ceramic process, and (b) WERF incinerator at INEL, (c) the super compaction and repackaging facility, and (d) microwave melting solidification at RFP, (e) the vitrification plant at SRS, and (f) the vitrification plant at WVDP.

\subsection{Idaho National Engineering Laboratory}

The INEL is located on a remote $890-\mathrm{mi}^{2}$ desert site on the Snake River Plain in Southeastern Idaho. Within this perimeter are nine nuclear research and development facilities. Additional office space is located in multiple locations in the City of Idaho Falls.

The INEL was established in 1949, when the Atomic Energy Commission needed a location for conducting nuclear research and development and nuclear-related defense work. The southeastern Idaho location was ideal because is was remote, large, and unpopulated.

Over the years, 52 nuclear reactors have been built at the INEL. While the majority were phased out after completion of their research mission, a few are still operating.

Current projects at the INEL include nonnuclear and nuclear energy programs. Waste management is a major project. It includes nuclear waste characterization, treatment, storage, and disposal.

Two treatment facilities/processes of potential interest to the GTCC LLW program are the Glass Ceramic Process currently planned at the Idaho Chemical Processing Plant (ICPP), and the Incineration Facility at WERF. Both are discussed further in this section.

\subsubsection{Glass Ceramic Process}

Lockheed Idaho Technologies Company

P.O. Box 1625

Idaho Falls, ID 83415

Status of Process: Planned 
Currently, high-level liquid wastes generated at the ICPP from reprocessing of irradiated government nuclear fuels are solidified in the New Waste Calcining Facility. ${ }^{5}$ Operating at a temperature of $500^{\circ} \mathrm{C}$, this is a fluidized bed process yielding a calcined waste that is stored near-surface in concrete encased stainless steel bins.

Development work at the ICPP has included the formulation of experimental glass-ceramic waste forms to immobilize the calcined HLW, and the conceptualization of processes to produce the waste forms. Present calcine waste loadings for a durable glass waste form are in the range of $33 \mathrm{wt} \%$, and would result in large volumes of immobilized waste. Research at the ICPP has shown that a glassceramic waste form, having a calcine waste loading of about $70 \mathrm{wt} \%$ and leaching properties comparable to a glass, can be achieved. It is estimated from formulations developed on a laboratory scale that the use of a glass-ceramic process and waste form could result in about $60 \%$ less immobilized waste volume as compared to the glass waste form and process.

The process consists of loading sized calcine particles, frit and other required additives into a process can. The can is evacuated of air and subjected to high temperatures and pressures which deforms the process cans and forms the waste glass ceramic. Each of these steps will now be discussed.

The proposed treatment process for the production of an acceptable glass-ceramic waste form would begin with the receipt of calcine into a Waste Immobilization Facility. The calcine feed would be sent to a stabilization unit, where nitrates and water previously absorbed in the calcine surface would be volatilized. A particle sizing step would be performed to reduce the particle size distribution span. The calcine composition would be analyzed as it enters the blender to determine the composition of the frit and reactants. These additives would be sized similar to and thoroughly mixed with calcine.

The calcine-additive mixture would be loaded into a processing can for the densification process. Air in the filled process can would be evacuated, then the can would be sealed, and surface cleaned. Fully dense, or near fully dense, glass-ceramic waste forms are attainable under high temperature and pressure over a predetermined process time. The densification temperature would need to be between 950 and $1,050^{\circ} \mathrm{C}$. Pressures of about 5,000 psi are required to effectively deform the processing cans. The process time is dependent on particle size and the glass-ceramic composition. However, process times of 1 hour have been used to form good glass-ceramic products. The estimated can reduction based on experimental work is approximately a $10 \%$ change in diameter and a $30 \%$ change in height, reducing the can dimensions from 27.5 to $24.75 \mathrm{in}$. in diameter and from a $129 \mathrm{in}$. height to $90 \mathrm{in}$.

After densification, the process cans would be decontaminated, stacked two at a time into a waste canister, and the waste canister sealed. The waste canisters would be stored and then shipped offsite to a geologic repository.

The process is assumed to operate on a $24-\mathrm{hr} /$ day schedule for the equivalent 250 full production days per year, which is approximately a $70 \%$ onstream efficiency. The average daily throughput for the facility, based on a $70 \%$ onstream efficiency, would be approximately 1.3 waste canisters per day. It is assumed the project startup date for the facility is FY-2014. A total of 8,500 canisters would be produced between FY-2014 and FY-2040.

Major limitations of vitrification were discussed previously. No specific limitations for the glassceramic process under study at ICPP were identified. 


\subsubsection{WERF Incinerator}

\section{Lockheed Idaho Technologies Company}

P.O. Box 1625

Idaho Falls, ID 83415

\section{Status of Process: Nonoperational}

The WERF incinerator began processing radioactive waste in September 1984.,7 The incinerator operated until February 1991, when it was shutdown by EG\&G Idaho, Inc. because of operational concerns. Subsequently, DOE applied Type III Startup Requirements to the WERF Restart Project because the facility had been shut down for more than 6 months. The WERF incinerator is currently nonoperational, and is awaiting the completion of a site-wide Environmental Impact Statement to be completed before restart.

The incinerator is a commercially available $1,465 \mathrm{~kW}$, dual chambered, controlled-air unit with a completely dry offgas treatment system. Originally designed for solid waste, the incinerator is capable of burning $181 \mathrm{~kg}$ of combustible material per hour.

Combustible solid waste comes to WERF packaged in cardboard boxes lined with polyethylene bags. These boxes are placed on a roller conveyor for transporting through a waste-characterization system. This system consists of a beta/gamma detector used to verify that radiation levels do not exceed incineration limits, an $x$-ray monitor used to inspect the boxes for undesirable types of wastes (metal items, liquids, etc.) and a weigh scale used to monitor the waste feed rate.

After characterization, the boxes are conveyed through an air lock and up via elevator to a vertical waste loading chute. The chute has a compartment and three doors to isolate the compartment and the combustion chamber from each other. When initiated by an operator, the top door opens and the box is loaded into the compartment, landing on the center door. After the top door has closed, the other two doors simultaneously open, dropping the box into the combustion chamber. In this manner two doors serve as an air lock, preventing air leakage into the incinerator and contamination spreading out of the incinerator during waste loading. The lower door, which is refractory lined, serves as a heat shield to prevent a box from igniting while in the chute compartment and to prevent a large heat loss out of the incinerator.

Both incinerator chambers are lined with a high alumina refractory and are equipped with oil-fired burners for heatup and temperature control. Air blowers provide combustion air. The combustion air is introduced into the primary chamber through a series of underfire air ports. The combustion air is controlled to maintain a slightly-oxygen deficient condition in the lower chamber, resulting in a quiescent burn that releases volatile gases but minimizes particulate carry-over into the secondary chamber. As the hot volatile gases enter the secondary chamber, excess air is injected to bring about complete combustion.

When burning solid waste, approximately 40 boxes are fed into the lower combustion chamber one at a time at roughly 6-minute intervals. After approximately 4 hours, the nonvolatile, carbonaceous heel remaining in the lower chamber is burned out by discontinuing waste feed and slowly changing to an excess-air mode. The burnout period takes approximately 4 more hours. After the heel is burned out, waste feeding begins again, and the cycle is repeated. The waste throughput rate is $181 \mathrm{~kg} / \mathrm{hr}$. 
The ash ram at the front of the lower combustion chamber periodically strokes about $25 \%$ of the hearth length, pushing the ash pile slowly toward the rear of the chamber, where it eventually falls into a hopper for cooling and removal. A 55-gal drum with a rigid polyethylene liner is used to receive ash from the drumming system for storage and subsequent burial. The drum is hydraulically positioned against a sealing gasket at the bottom of the ash drumming system. When the ash is sufficiently cool, the upper feed gates are hydraulically opened to fill the middle transition section. The feed gates are then closed and the isolation gate valve opened to deposit a fixed volume of ash into the drum. The cycle is repeated until the drum is full. The drum is removed and the ash mixed with wet cement and solidified. This process binds the ash in a concrete monolith, reducing leachability to the point that the resultant waste form is not hazardous. As a result, this waste form is classified as LLW and sent to the RWMC for disposal.

Exhaust gas exits the incinerator upper chamber at approximately $1,150^{\circ} \mathrm{C}$. Dilution air is immediately introduced to reduce the temperature to $<760^{\circ} \mathrm{C}$ before the gas enters the heat exchanger. The heat exchanger, a tube-in-shell parallel flow unit, which consists of $11711 / 4$-in. stainless steel tubes, further reduces the temperature to $<455^{\circ} \mathrm{C}$. Before filtration, facility ventilation air is introduced to further reduce the offgas temperature to $<175^{\circ} \mathrm{C}$. The cooled gases are passed through a fabric filter baghouse for initial removal of particulates. The prefiltered gases are then passed through a bank of high-efficiency particulate air (HEPA) filters. This series filtration system results in a $99.997 \%$ removal efficiency for particulates larger than $0.3 \mu$. The offgas is discharged to a $50-\mathrm{ft}$ main stack, which is instrumented to measure exhaust gas parameters (e.g., temperature, flow, opacity, $\mathrm{SO}^{2}$ content, and radioactive particulate).

Several disadvantages of the incineration processes were identified previously in the report. No specific limitations were identified for the WERF Incinerator.

\subsection{Rocky Flats Plant}

In 1952, the Atomic Energy Commission, early predecessor to the DOE, selected the Rocky Flats site to construct a facility for use in the nation's nuclear defense strategy. The primary mission of Rocky Flats until January 1992, was the manufacture of nuclear and nonnuclear components for nuclear weapons. Current operations include cleanup of waste generated during the nuclear weapon component manufacturing.

The RFP is approximately 16 miles northwest of downtown Denver on 384 acres in the center of a 6,550-acre reservation.

Two treatment facilities of potential interest for future treatment of GTCC LLW are the Super Compaction and Repackaging Facility and the Microwave Melting Solidification Facility.

\subsubsection{Super Compaction and Repackaging Facility}

EG\&G Rocky Flats

P.O. Box 464 Bldg. 776

Golden, CO 80402-0464

Status of Process: Operational 
The super compactor facility at Rocky Flats Plant was planned for the compaction of mixed waste only. With decontamination of the facility, it could be used for low-level radioactive waste. The entire process, from beginning to end, is performed within the confines of a glovebox. Remote operations ensure worker radiation doses are as low as reasonably achievable.

Waste streams are categorized as either hard waste or soft waste. Volume reduction of hard waste (i.e., metal, wood, concrete) is $85 \%$ or better. A slightly smaller volume reduction occurs in soft waste, that is, wastes containing high amounts of plastic and rubber. These resilient materials tend to "spring back" after the compaction process.

The hard waste stream (wood, metal, and concrete) is delivered directly in 35-gal drums to the Super compactor for processing. A conveyor moves each drum to a venting station for piercing before super compaction. Once this is done, the drum moves to the end of the input conveyor, where it is loaded into the press. The drum is centered on the press, and the press mold is closed around the drum. The drum is then compacted with a force of 2,200 tons. After the compaction cycle, the press mold is opened and the compacted drum (puck) is loaded into a 55-gal overpack drum for storage. Depending on the material compacted, approximately 3 to 10 pucks can fit into each overpack drum.

To process the soft waste stream (paper, plastic, rubber and glass), empty 35-gal drums are delivered to a 15-30 ton precompactor. The soft waste is loaded into the drum and precompacted. When the drum is full it is closed and returned to the main input conveyor where it is processed in a manner identical to the hard waste drums. Depending on the material compacted, approximately three to eight compacted pucks fit into each overpack drum.

Specific limitations exist for materials that can be treated by compaction. The materials must be compactible, free of all liquid, and strictly controlled radiologically to prevent any possibility of criticality.

The facility is capable of compacting and repackaging up to 10 drums per day.

\subsubsection{Microwave Melting Solidification}

EG\&G Rocky Flats

P.O. Box 464 Bldg. 750

Golden, CO 80402-0464

Status of Process: Planned

The current Microwave Solidification project began in 1985 with an initial focus on the use of microwave energy to dry sludge. ${ }^{8,9}$ The project has now matured into a full-scale demonstration system, which is currently being evaluated as a method to solidify waste. Currently, the full-scale microwave solidification facility is being tested with cold waste. To date, cold waste successfully processed includes precipitation sludge, incinerator ash, nitrate salts, and soils.

The process for microwave solidification treatment involves the accumulation of slurry material. The slurry is introduced into a glovebox then passed through a rotary drum vacuum filter precoated with a diatomaceous earth filter media to remove the solids from the waste stream. A thin layer of filter cake 
is continuously cut from the drum filter, producing a wet sludge. The sludge is fed by conveyor belt into a $50 \mathrm{~kW}, 915 \mathrm{MHz}$ microwave dryer. The dried material is transferred to a surge hopper, where it is accumulated before the melting process.

To begin the process, a 30-gal stainless steel drum is positioned to couple with the applicator cavity by placing it in an insulated cage and raising it to contact a rotary choke mechanism using a lifting turntable. To initiate microwave melting, an initial 10-kg charge of waste material is added to the drum while the turntable oscillates continuously to assure an even distribution of the waste in the drum. Microwave energy is transmitted into the $30 \mathrm{gal}$ drum, thereby raising the temperature of the waste material to approximately $1,000^{\circ} \mathrm{C}$, thereby causing it to melt. After the initial charge becomes molten, waste material is continuously transferred from the surge hopper at a feedrate of $24.5 \mathrm{~kg} /$ hour to the 30 -gal drum through a vibrating feeder, which penetrates the wall of the applicator cavity.

The process continues until $160 \mathrm{~kg}$ of processed waste material accumulates in the 30 -gal drum, approximately 6.5 hours. At this time, the process is momentarily interrupted while the drum is removed from the insulated cage and transferred to a cool-down/inspection station and an empty drum positioned to accept waste. The full drum is allowed to cool, then it is transferred to the bagless posting system for removal from the glovebox.

Effluent gases generated during the melting process are removed by ventilating the melting cavity using a down-stream blower system. Suspended particulates are removed from the effluent gas by passing the stream through a high efficiency cyclone and a sintered metal filter. The temperature of the effluent gas is reduced by means of a spray quencher and demister system. Finally, the clean effluent is passed through a roughing filter before entering the building filter plenum system, where it is polished through several stages of HEPA filtration.

Because the material does not have to flow, viscosities of the melt can be higher than typical vitrified glasses, allowing much higher waste loadings of up to $70 \%$, and greater densities near $3.0 \mathrm{~g} / \mathrm{cc}$. The equipment is relatively inexpensive and easy to maintain. An additional benefit is the high degree of public acceptance based on the fact that microwave energy is used and that it is in-container treatment.

One limitation of the process is the problem of arcing when metal components are processed. Based on this limitation, if metal is introduced into the feed, it must be shredded and ground to minimal size.

\subsection{Savannah River Site}

The SRS near Aiken, South Carolina, is a major DOE installation for the production of national defense nuclear materials. It began operations in the early 1950's.

The site is located on $300 \mathrm{mi}^{2}$ that form a rough circle about 20 miles in diameter.

The Savannah River Site currently contains over 3,000 facilities including 740 enclosed buildings. Despite the large number of facilities, only $5 \%$ of the land is developed. The major developed areas, located near the north boundary, include fabrication facilities for manufacturing reactor fuel and target assemblies. Five production reactors form a circle near the center of the site. Two fuel and product reprocessing centers are located northwest of the reactors near the waste management and future waste 
solidification facilities. The site administration and research and development facilities are near the northwest boundary.

The one treatment facility of interest to the GTCC LLW program is the Vitrification Plant at the Defense Waste Processing Facility (DWPF).

\subsubsection{DWPF Vitrification Plant}

Westinghouse Savannah River

P.O. Box 616, Building 704-355

Aiken, SC 29802

Status of Process: Under Construction

The waste generated from over thirty years of reprocessing of irradiated nuclear fuels for national defense purposes is stored at SRS. Approximately 130 million liters of alkaline waste are currently stored in underground carbon steel tanks in the SRS Tank Farm. This waste will be the feed stream for the new vitrification facility at the DWPF. ${ }^{10}$

The feed to the glass production process in the DWPF will consist of three streams: sludge $-28 \mathrm{wt} \%$, precipitated hydrolysis aqueous (PHA)-8 wt\%, and glass frit-64 wt\%. The sludge is the insoluble solids fraction of the waste in the Tank Farm, and contains nearly all of the long-lived radionuclides in the waste. Before vitrification, the sludge will undergo processing in the Tank Farm to remove soluble salts, and further processing in the DWPF to remove mercury.

The PHA is derived from the soluble portion of the waste in the Tank Farm. The soluble wastes are treated with sodium tetraphenylborate in the Tank Farm to remove radioactive cesium by precipitation, and with sodium titanate to absorb trace quantities of plutonium and strontium. The solid materials that now contain most of the radioactivity from the soluble waste are separated from the soluble salts by filtration. This slurry is then reacted with formic acid in the DWPF to remove most of the organic material by hydrolysis. The aqueous product from this hydrolysis process (PHA) is mixed with the sludge in the Sludge Receipt and Adjustment Tank. The slurry is then passed forward to the Slurry Mix Evaporator (SME) where the frit is added.

Each macro-batch of sludge and precipitate will be analyzed for its chemical composition and radionuclide inventory. This analysis is needed to verify that the correct frit composition has been specified.

Frit comprises the chemical constituents necessary to provide a durable borosilicate waste glass product. The constituents that make up an example batch of frit called Frit 202 includes major oxide components, $\mathrm{SiO}_{2}, \mathrm{Na}_{2} \mathrm{O}, \mathrm{B}_{2} \mathrm{O}_{3}, \mathrm{Li}_{2} \mathrm{O}$, and $\mathrm{MgO}$. Minor frit components include $\mathrm{Al}, \mathrm{Fe}, \mathrm{Mn}, \mathrm{Ni}, \mathrm{Cr}$, $\mathrm{Pb}, \mathrm{Ti}, \mathrm{F}$, and $\mathrm{Cl}$. Actual frit composition varies as needed to assure the production of waste glass that meets disposal requirements. The frit is blended into the waste slurry in the SME. Approximately $90 \%$ of the necessary frit is pumped directly to the SME. The remaining $10 \%$ is used for canister decontamination (frit blasting) first, then added to the SME. No feed will be allowed to leave the SME until it has been determined that the feed will make acceptable glass. 
Following acceptance, the SME batch is transferred to the Melter Feed Tank (MFT). Each MFT batch is sampled and the analytical results, along with those from the SME, used to report the chemical composition of the macro-batch.

Vitrification of SRS waste is accomplished in a Joule-heated, slurry-fed melter. The feed slurry is introduced from the top of the melter through feed tubes. The melt is maintained at a nominal temperature of $1,150^{\circ} \mathrm{C}$, by electric current passing through the melt from two pairs of opposing electrodes. The resistance of the molten glass converts the electrical energy into heat. The nominal melter residence time is about 65 hours, which allows ample time for the melt to homogenize via thermal convection currents.

Four pairs of horizontal resistance heaters are installed in the vapor space of the melter vessel. These heaters supply the heat which initially melts the glass at melter startup. During normal operations, the heaters are kept at $950^{\circ} \mathrm{C}$ to maintain the melter plenum vapor space at 600 to $800^{\circ} \mathrm{C}$.

During the pour cycle, the molten glass (at a nominal temperature of 1,050 to $1,100^{\circ} \mathrm{C}$ ) is drawn through the melter throat near the bottom of the melter, up into a heated riser, and down a heated pour spout into a stainless steel canister. (The waste canister is $2-\mathrm{ft}$ in diameter and 10- $\mathrm{ft}$ in height. Each canister holds up to 3,700 lb of waste glass.) A pour spout bellows assembly connects the pour spout and the canister, providing a flexible, leak-tight seal between them. Glass is poured from the melter by establishing a vacuum above the canister nozzle. This pressure differential causes the glass to flow out of the melter, through the riser, and into the canister.

Approximately 16 hours is required to fill one canister at a throughput rate of $230 \mathrm{lb} / \mathrm{hr}$. After filling, the canister remains connected to the pour spout for 15 minutes to vent radioactive gases. After the canister has been filled and vented, the pour spout bellows is disengaged and the canister is rotated out from under the melter pour spout. An inner canister closure plug is inserted into the nozzle of the canister to make a temporary shrink-fit seal. The purpose of this seal is prevention of water entry into the canister during decontamination.

Following decontamination, a plug will be upset-resistance welded into the canister nozzle. The canister is then transferred to an air-cooled vault for interim storage before shipment to a Federal repository.

The vitrification facility at DWPF is in the final stages of construction. The facility is scheduled for cold waste processing in June 1994 followed by hot waste processing startup in December 1995.

Major limitations of vitrification were discussed previously; there are no specific limitations for the DWPF vitrification facility.

\subsection{West Valley Demonstration Plant}

The only commercial nuclear fuel reprocessing facility ever to operate in the United States is located on approximately 200 acres near West Valley, New York.

From 1966 to 1972 , the plant chemically reprocessed approximately 640 metric tons of spent nuclear fuel to recover useable uranium and plutonium. Nearly 600,000 gallons of liquid HLW, a by- 
product of reprocessing, is stored in an underground tank contained within a concrete vault. In 1976, the operator ceased operations.

In 1980, the West Valley Demonstration Project Act was signed enacting Public Law 96-368. The Act directs the DOE to: solidify the HLW stored at the site into a durable, solid form suitable for shipment to a Federal repository, clean and close the facilities used, and dispose of the low-level and TRU wastes collected during project operations.

The one treatment facility of interest to the GTCC LLW program is the Vitrification Plant at the WVDP.

\subsubsection{WVDP Vitrification Facility}

Westinghouse

P.O. Box 191

West Valley, NY 14171

Status of Process: Under Construction

Within the HLW storage tank, the nearly 600,000 gallons of waste has separated into two layers; a relatively clear liquid layer and a thick layer of sludge. The solidification of this waste into glass will be conducted in two stages. In the first stage, the liquid is passed through a synthetic clay material which removes over $99.9 \%$ of the radioactivity. The nearly decontaminated liquid is then concentrated, blended with cement, placed in 71-gal steel drums and stored in an aboveground, onsite facility. To date, 80\% of the radioactivity has been removed from the liquid portion of the HLW, resulting in 11,000 drums of cemented waste being produced.

The second stage of processing is vitrification. During this stage, the sludge layer will be washed and thoroughly mixed within the storage tank and pumped in batches to the vitrification facility. In the feed tank, the synthetic clay material (which contains the radioactivity removed from the liquid) will be blended with the sludge. The waste batch will be held for sampling and analysis verifying the proper formulation of frit material to be added. This ensures that the resultant waste glass is acceptable for disposal. Following analysis, glass-forming frit will be combined with the waste.

Vitrification is accomplished in a Joule-heated, sludge-fed, 52-ton melter. The sludge will be introduced from the top of the melter. The glass melt is maintained at a nominal temperature of $1,150^{\circ} \mathrm{C}$, by electric current passing through the melt. At this temperature, a uniform molten waste/glass blend is formulated. Similar to the Savannah River Vitrification Facility, the current is supplied to the melt by two pairs of opposing electrodes. The resistance of the molten glass converts the electrical energy into heat.

The borosilicate glass waste form will be poured into stainless steel waste canisters for storage. Each canister is $2 \mathrm{ft}$ in diameter and $10 \mathrm{ft}$ in height and holds up to $3,700 \mathrm{lb}$ of waste glass.

Approximately 16 hours is required to fill each canister at a throughput rate of $230 \mathrm{lb} / \mathrm{hr}$. After filling, the canister remains connected to the pour spout for 15 minutes to vent radioactive gases. 
Following decontamination, a plug will be welded into the canister nozzle. The canister will be stored onsite awaiting transport to a Federal repository.

The vitrification facility at West Valley is under construction. The facility is scheduled to start cold waste processing in 1996.

Major limitations of vitrification were discussed previously. No specific limitations for the WVDP vitrification facility are identified. 


\section{CONCLUSIONS AND RECOMMENDATIONS}

Within the DOE complex, facilities exist to treat LLW and HLW per DOE Order 5820.2A. Although potentially capable of treating at least some GTCC waste streams (subject to characterization findings), none are treating or plan to treat GTCC LLW in the foreseeable future. Introducing GTCC LLW as an added waste stream to operational or nearly operational facilities would greatly upset planned activities and generate substantial delays. Therefore, based on the investigation performed for this report, it is recommended that:

- A full physical and chemical characterization of each GTCC waste stream be performed as a basis for selecting specific treatments. Without such a characterization it is not possible to predict the result of selecting any treatment process, particularly vitrification and incineration.

- DOE approve multiple treatments for GTCC LLW to permit matching various waste streams to treatment parameters. Such treatments might be sizing and packaging of metals, chemical dissolution or incineration for organics, and vitrification for wastes that can be pretreated to make sludge.

- National Low-Level Waste Management Program personnel investigate the possibility of including some GTCC waste streams as constituent feed for PNL's Low-Level Waste Vitrification Facility that is currently in the early stages of preconceptual design.

- National Low-Level Waste Management Program personnel initiate a feasibility study to determine if the microwave melter at Rocky Flats could serve as a "best available technology" treatment for some GTCC waste streams. Being a small batch (30 gal/cycle) operation, this technology is scaled to match the small volumes identified as GTCC LLW.

- DOE not include any GTCC LLW as an added feed for the vitrification facilities at Savannah River or West Valley. Both these facilities are well into construction and testing, introducing GTCC LLW now would present a range of problems that would be expensive to solve.

- National Low Level Waste Management Program personnel initiate a feasibility study to determine if the private sector has any interest in treating GTCC LLW.

- DOE approve combining GTCC LLW with SCW, a waste that is government-generated and has characteristics equivalent to GTCC LLW. The substantial increase in waste volume resulting from this union would greatly enhance the economics of any treatment undertaking. 


\section{REFERENCES}

1. DOE Order 5820.2A, "Radioactive Waste Management," September 26, 1988.

2. T. W. Garrison and D. K. Fischer, Greater-Than-Class CLow-Level Radioactive Waste Treatment Technology Evaluation, DOE/LLW-159, EG\&G Idaho, Inc., January 1993.

3. Mixed and Low-Level Waste Treatment Facility Project-Volume 3 Waste Treatment Technologies, EGG-WMO-10244, EG\&G Idaho, Inc., April 1992.

4. Vitrification Technologies for Treatment of Hazardous and Radioactive Waste, EPA/625/R-92/002, U.S. Environmental Protection Agency, May 1992.

5. W. D. Bolon, J. D. Herzog, and A. L. Olson, Status Report: The Glass-Ceramic Processing Flowsheet for ICPP High-Level Waste, WINCO-1090, Westinghouse Idaho Nuclear Company, Inc., December 1991.

6. R. L. Gillins, J. N. Davis, R. Y. Maughan, and J. A. Logan, Low-Level Waste Incineration at the Idaho National Engineering Laboratory, EG\&G Idaho, Inc., EGG-M-02585, 1985.

7. R. L. Gillins and M. M. Larsen, Low-Level and Mixed Waste Treatment at the Idaho National Engineering Laboratory, EG\&G Idaho, Inc., EGG-M-88436, 1988.

8. R. D. Petersen and G. S. Sprenger, Microwave Waste Processing Technology Overview, EG\&G Rocky Flats, Inc., November 1993.

9. G. S. Sprenger, Microwave Solidification Project Overview, EG\&G Rocky Flats, Inc., November 1993.

10. S. L. Marra and M. J. Plodinec, DWPF Glass Product Control Program, WSRC-IM-91-116-6 Revision 0, Westinghouse Savannah River Company, November 1992. 
Appendix A

Greater-Than-Class C Low-Level

Waste Characterization 
A-2 


\section{Appendix A}

\section{Greater-Than-Class C Low-Level Waste Characterization}

A number of commercial facilities generate potential Greater-Than-Class C Low-Level Waste (GTCC LLW). These facilities are:

- Carbon-14 users

- Fuel fabricators

- Medical research institutions

- Nuclear utilities

- Industrial research and development firms

- Nuclear research reactors

- $\quad$ Sealed source distributors

- Sealed source manufacturers

- Nonmedical academic institutions

- Nonresearch medical institutions

- Analytical laboratories

- Waste service companies

- Manufacturers of devices containing sealed sources.

The GTCC LLW waste stream generators listed above are grouped by Department of Energy (DOE) into four general categories. Each is discussed in this section. The GTCC LLW is categorized as:

- Nuclear utilities waste

- Sealed sources waste

- DOE-held potential GTCC LLW

- Other generator waste. 


\section{A-1. NUCLEAR UTILITIES WASTE}

Operators of light water reactors (pressurized water reactors and boiling water reactors) are the major GTCC LLW generators. ${ }^{A-1}$ The potential GTCC LLW generated is dictated by the manufacturer's design and operating practices. The GTCC LLW from nuclear utilities include activated metals from standard operations, process wastes such as decontamination resins and cartridge filters, and decommissioning waste. Table A-1 contains the anticipated volumes of untreated and unpackaged activated metals. Table A-2 contains the anticipated volumes of untreated process wastes.

Table A-1. GTCC activated metal reactor components."

\begin{tabular}{cc} 
Component & $\begin{array}{c}\text { Unpackaged } \\
\text { volume } \\
\left(\mathrm{m}^{3}\right)\end{array}$ \\
\hline
\end{tabular}

BWR core shroud

81.4

BWR orificed fuel support

.074

BWR fuel guide

Control rod blades

64.3

Local power range monitors

14.08

Primary source/source rods

1.95

PWR core shroud

87.1

PWR crud tank filters

1.63

PWR in-core instruments

56.42

PWR miscellaneous cartridge filters

40

Dry tubes

Thimble plug assemblies

PWR lower core support plates

29.38

PWR upper core support plates

29.38

Total

a. M. R. Winberg, Greater-Than-Class C Low-Level Radioactive Waste Characterization: Estimated Volumes, Radionuclide Activities, and Other Characteristics, Revision 1, DOE/LLW-114, September, 1994. 
Table A-2. GTCC reactor process wastes. ${ }^{2}$

\begin{tabular}{lc}
\hline \multicolumn{1}{c}{$\begin{array}{c}\text { Component } \\
\text { (estimated for year 2035) }\end{array}$} & $\begin{array}{c}\text { Unpackaged } \\
\text { volume } \\
\left(\mathrm{m}^{3}\right)\end{array}$ \\
\hline BWR fuel-in decontamination resins & 33.96 \\
BWR inner and outer control rod drive strainers & 15.64 \\
BWR pool filters & 10.94 \\
PWR fuel-in decontamination resins & $\underline{87.87}$ \\
Total & 148.41 \\
\hline & \\
a. & \\
Volumes, Radionuclide Activities, and Other Characteristics, Revision 1, DOE/LLW-114, September, 1994. \\
\hline
\end{tabular}




\section{A-2. SEALED SOURCES WASTE}

Sealed sources are typically small metallic containers encapsulating relatively high-activity, radioactive material. ${ }^{\mathrm{A}-2}$ Source activities range from less than $1 \mathrm{mCi}$ to over $1,000 \mathrm{Ci}$. However, most sources have activities less than $100 \mathrm{mCi}$. The source is often placed into a device used for performing some type of measurement. These devices have common uses in medicine, construction, manufacturing, research and various other fields. Sealed sources become waste when they are no longer needed or the radioactivity has decayed to the point that they are no longer usable. Although sealed sources are considered GTCC LLW, they are not expected to be accepted by DOE as waste. They will be accepted by DOE as radioactive material for storage, reuse, or recycle. Typical uses of sealed sources include:

- Calibration devices

- Medical therapy

- Well logging devices

- Portable gauges

- Irradiation

- Fixed gauges

- General neutron applications

- $\quad \mathrm{X}$-ray fluorescence sources.

Table A-3 contains a summary of applications using radioactive sealed sources, the isotopes involved, and typical and maximum activity levels. 
Table A-3. Summary of applications using radioactive sealed sources that are GTCC LLW.*

\begin{tabular}{|c|c|c|c|c|}
\hline Device type & Method & Isotope & Typical activity & $\underset{\text { activity }}{\text { Maximum }}$ \\
\hline Calibration & NA & $\begin{array}{l}\text { Am-241 } \\
\text { Cs-137 }\end{array}$ & $\begin{array}{l}<500 \mathrm{mCi} \\
<1 \mathrm{Ci}\end{array}$ & $\begin{array}{l}1 \mathrm{Ci} \\
2 \mathrm{kCi}\end{array}$ \\
\hline Medical & $\begin{array}{l}\text { Radiography } \\
\text { Teletherapy } \\
\text { Brachytherapy }\end{array}$ & $\begin{array}{l}\text { Am-241 } \\
\text { Cs-137 } \\
\text { Cs-137 }\end{array}$ & $\begin{array}{l}<100 \mathrm{mC} \\
1.25-2.5 \mathrm{kCi} \\
1-10 \mathrm{mCi}\end{array}$ & $\begin{array}{l}30 \mathrm{Ci} \\
2.5 \mathrm{kCi} \\
500 \mathrm{mCi}\end{array}$ \\
\hline Well logging & $\begin{array}{l}\text { Neutron thermalization } \\
\text { Gamma scattering }\end{array}$ & $\begin{array}{l}\text { Am-241 } \\
\text { Pu-238 } \\
\text { Cs-137 }\end{array}$ & $\begin{array}{l}6-16 \mathrm{Ci} \\
6-16 \mathrm{Ci} \\
<500 \mathrm{mCi}\end{array}$ & $\begin{array}{l}20 \mathrm{Ci} \\
20 \mathrm{Ci} \\
5 \mathrm{Ci}\end{array}$ \\
\hline Portable gauge & $\begin{array}{l}\text { Neutron thermalization } \\
\text { Gamma scattering }\end{array}$ & $\begin{array}{l}\text { Am-241 } \\
\text { Cs-137 }\end{array}$ & $\begin{array}{l}40-50 \mathrm{mCi} \\
5-15 \mathrm{mCi}\end{array}$ & $\begin{array}{l}5 \mathrm{Ci} \\
1 \mathrm{Ci}\end{array}$ \\
\hline Irradiation & NA & Cs-137 & $1-5 \mathrm{kCi}$ & $20 \mathrm{kCi}$ \\
\hline Fixed gauge & $\begin{array}{l}\text { Photon switch } \\
\text { XRF } \\
\text { Gamma absorption }\end{array}$ & $\begin{array}{l}\text { Sr-90 } \\
\text { Am-241 } \\
\text { Cs-137 } \\
\text { Am-241 } \\
\text { Cs-137 } \\
\text { Pu-238 } \\
\text { Am-241 } \\
\text { Cs-137 } \\
\text { Am-241 } \\
\text { Pu-238 } \\
\text { Am-241 }\end{array}$ & $\begin{array}{l}>500 \mathrm{mCi} \\
0.01-0.5 \mathrm{Ci} \\
0.01-0.5 \mathrm{Ci} \\
100 \mathrm{mCi} \\
50 \mathrm{mCi} \\
25 \mathrm{mCi} \\
100 \mathrm{mCi} \\
0.05-2 \mathrm{Ci} \\
0.1-0.5 \mathrm{Ci} \\
25 \mathrm{mCi} \\
10 \mathrm{mCi}\end{array}$ & $\begin{array}{l}1 \mathrm{Ci} \\
1 \mathrm{Ci} \\
1 \mathrm{Ci} \\
1 \mathrm{Ci} \\
1 \mathrm{Ci} \\
1 \mathrm{Ci} \\
1 \mathrm{Ci} \\
2 \mathrm{Ci} \\
1 \mathrm{Ci} \\
100 \mathrm{mCi} \\
\mathrm{NA}\end{array}$ \\
\hline $\begin{array}{l}\text { General neutron } \\
\text { applications }\end{array}$ & $\begin{array}{l}\text { Neutron capture and } \\
\text { activation analysis } \\
\text { Neutron transmission }\end{array}$ & $\begin{array}{l}\text { Am-241 } \\
\text { Am-241 }\end{array}$ & $\begin{array}{l}1-100 \mathrm{Ci} \\
0.25-1 \mathrm{Ci}\end{array}$ & $\begin{array}{l}100 \mathrm{Ci} \\
1 \mathrm{Ci}\end{array}$ \\
\hline $\begin{array}{l}\text { X-ray } \\
\text { fluorescence }\end{array}$ & & $\begin{array}{l}\text { Am-241 } \\
\text { Pu-238 }\end{array}$ & $\begin{array}{l}1-1,000 \mathrm{mCi} \\
1-1,000 \mathrm{mCi}\end{array}$ & $\begin{array}{l}1 \mathrm{Ci} \\
1 \mathrm{Ci}\end{array}$ \\
\hline Other & Nuclear battery & $\begin{array}{l}\text { Pu-238 } \\
\text { Sr-90 }\end{array}$ & $\begin{array}{l}4-6 \mathrm{Ci} \\
\mathrm{NA}\end{array}$ & $\begin{array}{l}35 \mathrm{Ci} \\
20 \mathrm{kCi}\end{array}$ \\
\hline
\end{tabular}

a. Gerald Harris, Characterization of Greater-Than-Class C Sealed Sources; Volume 2: Sealed Source Characterization and Future Production, DOE/LLW-163, September 1994, Table 3-1. 


\section{A-3. DOE-HELD POTENTIAL GTCC LLW}

A few commercial facilities have generated potential GTCC LLW that through contractual arrangements with DOE and/or for health and safety reasons is being stored by DOE. ${ }^{A-3}$ Table $A-4$ summarizes the waste stored at various DOE facilities as of February 25, 1993. It has been determined that the inventory of DOE-Held potential GTCC LLW will not require management under Public Law 99-240. This waste will now be managed as DOE Special Case Waste (SCW). 
Table A-4. DOE-held potential GTCC LLW."

\begin{tabular}{|c|c|c|}
\hline Field office & Generator/user & Waste type \\
\hline \multirow[t]{4}{*}{ Idaho } & J.C. Haynes (OH) & $\begin{array}{l}\text { Solid trash, laboratory type of material, rags, plastic, } \\
\text { wood and small metal pieces }\end{array}$ \\
\hline & Monsanto (MO) & $\begin{array}{l}\text { Solid trash, stainless steel, plastic, rags, wood, small } \\
\text { tools, gloves, and radioactive sources }\end{array}$ \\
\hline & Three Mile Island (PA) & $\begin{array}{l}\text { Solid, Metal Oxide Assembly of CUNO cartridge } \\
\text { filters with filtrate. Lead is present in containers }\end{array}$ \\
\hline & Babcock and Wilcox (VA) & $\begin{array}{l}\text { Solid trash, cloth, paper, metal and plastic materials. } \\
\text { Compressible and/or combustible waste (fifteen } \\
\text { 55-gal drums) } \\
\text { Solid dry wastes (two 55-gal drums) Heavy section } \\
\text { materials, asphalt (two 55-gal drums) }\end{array}$ \\
\hline \multirow[t]{8}{*}{ Richland } & Sequoyah Fuels (OK) & $\begin{array}{l}\text { Solid waste, pipes, pump heads, wipes, rags, plastics, } \\
\text { etc. }\end{array}$ \\
\hline & $\begin{array}{l}\text { General Electric Vallecitos } \\
\text { (CA) }\end{array}$ & Solid waste, hoods, and associated materials \\
\hline & Babcock and Wilcox (PA) & $\begin{array}{l}\text { Solid waste, tanks, equipment, tools, cans, paper, } \\
\text { plastic, etc. }\end{array}$ \\
\hline & Westinghouse (PA) & Solid waste, equipment, tools, paper, hoods, etc. \\
\hline & Rockwell (CA) & $\begin{array}{l}\text { Solid Waste, equipment, tools, paper, cans, plastic, } \\
\text { etc. }\end{array}$ \\
\hline & U.S. Navy & Radioisotope Thermoelectric Generator \\
\hline & Three Mile Island (PA) & Zeolite Resin-Demineralizer System (SDS) Liners \\
\hline & Battelle Columbus $(\mathrm{OH})$ & $\begin{array}{l}\text { Sealed Source owned by U.S. Air Force } \\
\text { Some lead }\end{array}$ \\
\hline Nevada & U.S. Military (NV) & $\begin{array}{l}\text { Military thermoelectric source, generated and used in } \\
\text { Greater Confinement Disposal (GCD) at Nevada Test } \\
\text { Site }\end{array}$ \\
\hline Oak Ridge & Nuclear Fuel Services & Solid waste, pipes, pump heads, etc. \\
\hline Savannah River & Allied General Nuclear & Solid waste, stainless steel, saddles, deionizers, etc. \\
\hline
\end{tabular}




\section{A-4. OTHER GENERATOR WASTE}

The fourth category of GTCC LLW is Other Generator Waste. ${ }^{A-4}$ The waste generators that are identified in this category include Carbon-14 users, industrial research and development firms, fuel fabricators and irradiation research (burnup) laboratories, academic nuclear research reactors, sealed source manufacturers, and nonmedical academic institutions. The waste is currently being held by the generators of the waste. Table A-5 summarizes the waste streams in the other generator waste category.

Based on information available for the four general categories, GTCC LLW unpackaged volume is based upon Nuclear Utility Waste and Other Generators Waste. DOE-Held Potential GTCC LLW and Sealed Source waste is not included in GTCC LLW. The largest unpackaged volume of waste, approximately $54.2 \%$ is generated by commercial nuclear power plants. The other generator category contributes approximately $45.8 \%$ of the total GTCC LLW. 
Table A-5. Other generators.

\begin{tabular}{|c|c|c|}
\hline $\begin{array}{l}\text { Facility } \\
\text { ID }\end{array}$ & Business type & Waste description \\
\hline 1 & ${ }^{14} \mathrm{C}$ User & Organic liquids: solidified waste, tritium \\
\hline 2 & ${ }^{14} \mathrm{C}$ User & $\begin{array}{l}\text { Organic liquids: free liquid ( } 25 \% \text { water, } 75 \% \text { alcohols, acetone, } \\
\text { hexane, xylene, etc.) }\end{array}$ \\
\hline 3 & ${ }^{14} \mathrm{C}$ User & Organic liquids: damp, solidified calcium carbonate \\
\hline 4 & ${ }^{14} \mathrm{C}$ User & $\begin{array}{l}\text { Organic liquids: absorbed liquids, alcohols, aromatics, salts, } \\
\text { silica gel }\end{array}$ \\
\hline 5 & ${ }^{14} \mathrm{C}$ User & Organic liquids: free liquid \\
\hline 6 & Industrial R\&D & Mixed oxide fuel pellets/rods \\
\hline 7 & Burnup Lab & $\begin{array}{l}\text { Contaminated solids: hot cell waste (fuel grinds, } 25 \% \\
\text { compactible trash, glass, plastic, metal scrap, equipment) }\end{array}$ \\
\hline 8 & Burnup Lab & $\begin{array}{l}\text { Contaminated solids: hot cell waste (fuel grinds, } 25 \% \\
\text { compactible trash, glass, plastic, metal scrap, equipment) }\end{array}$ \\
\hline 9 & Fuel Fabricator & Decontamination waste: Sludge, filters, grit \\
\hline 10 & University Reactor & $\begin{array}{l}\text { Activated metals: control blades, miscellaneous in-core } \\
\text { components }\end{array}$ \\
\hline 11 & $\begin{array}{l}\text { Sealed Source } \\
\text { Manufacturer }\end{array}$ & $\begin{array}{l}\text { Process waste: absorbed liquids, compactible trash, filters, } \\
\text { glass, lead, plastic, metal scrap }\end{array}$ \\
\hline 12 & $\begin{array}{l}\text { Sealed Source } \\
\text { Manufacturer }\end{array}$ & Process waste: $\mathrm{AmO}_{2} /$ gold foil, scrap sources, glass \\
\hline 13 & $\begin{array}{l}\text { Nonmedical } \\
\text { Academic Inst. }\end{array}$ & Process waste: dry technetium salt \\
\hline $\begin{array}{r}\text { Lar } \\
\text { enerat }\end{array}$ & Fish, Characteriz & $\begin{array}{l}\text { of Greater-Than-Class C Low-Level Radioactive Waste from "Other } \\
\text { tember 1994, Table 2.A4 }\end{array}$ \\
\hline
\end{tabular}




\section{A-5. REFERENCES}

A-1. M. R. Winberg, Greater-Than-Class C Low-Level Radioactive Waste Characterization: Estimated Volumes, Radionuclide Activities, and Other Characteristics, Revision 1, DOE/LLW-114, EG\&G Idaho, Inc., September 1994.

A-2. Gerald Harris, Characterization of Greater-Than-Class C Sealed Sources; Volume 2: Sealed Source Characterization and Future Production, DOE/LLW-163, EG\&G Idaho, Inc., September 1994, Table 3-1.

A-3. Bill Allred, Letter to GTCC LLW Staff, Subject: DOE-Held Potential GTCC LLW from NRC or Agreement State Licensed Facilities, EG\&G Idaho, Inc., February 1993.

A-4. Larry W. Fish, Characterization of Greater-Than-Class C Low-Level Radioactive Waste from "Other Generators", DOE/LLW-114D-3, EG\&G Idaho, Inc., September 1994, Table 2. 